\author{
KÁDÁR, ZOLTÁN PHD
}

zoltaankadar@gmail.com

assistant professor (University of Szeged Faculty of Arts Department of Sociology)

\title{
Civilization Critical Investigation on the „Clockwork Condition” described by Anthony Burgess
}

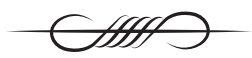

\begin{abstract}
The negative effects of the civilized lifestyle are widely discussed by many authors (for example Marx, Wells, or Max Nordau) in the nineteenth century, showing that industrial society and its mechanic requirements make a hard mental and physical impact on people who build and constantly change the modern world. In the twentieth century, many authors also dealt with the problem of adaptation to technology - a process that deeply changes people - that pushes them to a direction that leads towards an obedient, man-machine condition of life. Taylorism and its heritage, plus the culture, sport, sex, etc. industries and above all politics with its satellite media determine people how to live their lives. This makes a lifelong discomfort for those who want some autonomy but gives redemption for others who flee from constant decision-making. Burgess's „clockwork condition” is a great depiction of the (post)modern man whose actions are mostly mere responses to a mechanic milieu created by „the state" that uses people as tools. Even democracy can turn into a spiritless, alienated sequence impregnated with boring or obviously mad plans of a governing minority if citizens forget how to be conscious, creative, and responsible when they make decisions. Beyond the topic of the novel A Clockwork Orange the problem is general: do we choose the „forced marriage of an organism to a mechanism” and follow the given patterns, let the conditioning happen, or insist on being imperfect, but capable of making decisions, even if many of them are bad.
\end{abstract}

\section{KEYWORDS}

Anthony Burgess, Clokwork Condition, problem of adaptation, Taylorism 
DOI 10.14232/belv.2021.3.5

https://doi.org/10.14232/belv.2021.3.5

Cikkre való hivatkozás / How to cite this article: Kádár Zoltán (2021): Civilization Critical Investigation on the „Clockwork Condition” described by Anthony Burgess. Belvedere Meridionale vol. 33. no. 3. 90-96. pp

ISSN 1419-0222 (print)

ISSN 2064-5929 (online, pdf)

(Creative Commons) Nevezd meg! - Így add tovább! 4.0 (CC BY-SA 4.0)

(Creative Commons) Attribution-ShareAlike 4.0 International (CC BY-SA 4.0)

www.belvedere-meridionale.hu

When Anthony Burgess describes the „clockwork condition” in one of his writings after more than ten years of the appearance of his novel A Clockwork Orange and a short time after Stanley Kubrick's movie adaptation (it came out in 1972 in Britain) he states a very important thought about freedom and work. As he says „There is a bigger and more abiding consolation - the fact that I am free to write what I wish, that I have to follow no clock, that I need call no man "sir" and defer to him through fear. But such freedom breeds its own compunctions: I feel guilty if I do not work; I am my own tyrant. ... I recognize that I am better off than most, but I do not regard myself as having opted out of the agony and anxiety that plague men and women who are slaves to lives they did not choose and denizens of communities they hate."1

In the life of the writer work and freedom could be luckily paired in a content and steady way. These are brilliant sentences from a free man who is capable of free choice, accomplishing the art of living without lies, tactics, and other squalid actions. Burgess reveals the essence of the free intellectual mood of life as a writer and he knows how lucky he is. Success and contentment are very rare parts of the life of the majority of people of civilized countries. Alienation, hurry, deadlines, propaganda, professional wish makers with scientific-based advertisements, politics with its language that is not only reduced to a moron's level but it does not even say the truth, and last but not least the caste system in institutions, workplaces, etc. These things in democracies make life - or there is a good chance these phenomena do - miserable on many levels for almost everyone. Burgess had to fight for this „,winning” condition he describes in 1973 . He had many tyrants when he was a soldier or a public servant, there were rules, clocks, and sirs whom he needed to obey, but finally he won and swapped his tyrants. He for himself as a tyrant is much better than a-most times - less intelligent, less educated one who surpasses the subjugates in things like aggression or careerism.

Of course, the circumstances of workers, or more precisely wage-workers have changed a lot. The sequence of positive results can be traced back well from the beginning, that is (let's say) Marx's essay of alienated labor until the mid-20th century's evolving welfare states, where

Burgess 2012. 
- thanks to the Bernsteinist social democratic thinking and actions ${ }^{2}$ - the world of labor slowly was cottoned with measures and laws that defended workers (regardless of the color of the collar) from many dimensions. Despite the better salary, greater appreciation of workers, more safety and possibility of reaching a more convenient and plannable life and future some kind of spleen remained in the air and is still with us.

The phenomenon that Burgess called ,clockwork condition” was well scrutinized much earlier by Max Nordau, a Hungarian born Jewish writer, journalist, and physician (and later zionist leader) who in 1882 wrote his famous (or for many readers infamous) work titled Degeneration, and found many facts in his medical office in Paris that the new lifestyle - that had new characteristics such as the rule of the clock on people and a new kind of discipline conducted by the pace of the machine production makes people ill both physically and psychically. His more than five hundred pages diagnosis targets mainly the fin de siécle cultural milieu as a degenerative factor in art, literature, and philosophy, in order to show those tendencies that make degenerated leaders and cultural elite and through them degenerated future planning. There is a part in this book where Nordau as a doctor overstocks his readers with plenty of (well documented Prussian) statistics about many illnesses: how much the number of patients with mental problems, cardiac disease, alcoholism, or drug addiction increased in a decade. He points out the growing rate of felonies or suicides but also observes that the newer generations sooner meet hair or skin problems, teeth problems, and need to wear glasses because their vision capacities begin to decline earlier.

As Nordau notes ,all the symptoms enumerated are the consequences of fatigue and exhaustion, and these, again, are the effect of contemporary civilization, of the vertigo and whirl of our frenzied life, the vastly increased number of sense impressions and organic reactions, and therefore of perceptions, judgments, and motor impulses, which at present are forced into a given unity of time". ${ }^{3}$ This cocktail of tasks, speed, and compulsory decisions consists the greater part of the life of those unlucky ones who also had to throw their personal life into this vertigo and whirl and have no choice to turn themselves into their own tyrant. It is not surprising that they drink more alcohol, take more drugs or choose more often to commit suicide, or do crimes and mad things. Nordau warns his readers that the future can be much worse if the evident (at least for him) degenerative tendencies will follow, then be intensified and dominate the 20th century.

Interesting that Nordau partly envisioned the Karova Milkbar and the Ludovico treatment too, and was capable to super enhance the dystopic picture of the future ruled by degeneration: „... In the place of the present taverns houses would be found devoted to the service of consumers of ether, chloral, naphtha, and hashish. ... Sexual psychopathy of every nature has become so general and so imperious that manners and laws have adapted themselves accordingly. Modesty and restraint are dead superstitions of the past, and appear only as atavism and among the inhabitants of remote villages. The lust of murder is confronted as a disease, and treated by surgical intervention, etc" 4 .

\footnotetext{
Against the classical Marxism, for example Karl Kautsky, who forced class struggle and world revolution the Bernsternist way was of the reforms and the gradual improvement of the life of workers.

3 NORDAu 1895. 42.

4 Ibid 471-472.
} 
Modesty and restraint are strict basic constitutions of civilization and civilized behavior that need a system in the background which coerces people to learn it and also to apply it. Being a civilized human has a price, a great part of the autonomy of a person remains dumb because the state acts instead of the citizen in many cases, such as protecting him or giving him possibilities for living a decent life with many rules to keep. As Burgess says „fear of the whip drove

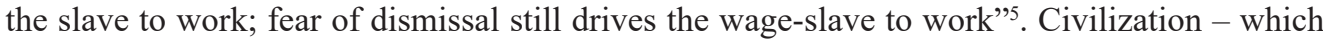
partially consists of some culture (but this ingredient is not really necessary) - is based on discipline, limited knowledge, a dose of fear, and a relatively narrow intellectual horizon for almost everyone. Long ago the closest mate of people became the machine, machinery has been the alignment point. As Herbert Marcuse notes life in industrial societies has lost its spontaneity or its adventure likeness. „Individual distinctions in the aptitude, insight, and knowledge are transformed into different quanta of skill and training, to be coordinated at any time within the common framework of standardized performances". ${ }^{6}$ The result is fatigue, but not the muscles are tired, rather the mind.

As Burgess points out problems of ends and means of society became apparent soon for the elite and it begins to think about solutions. These solutions of course do not concern the elite as the focus of the problems but the people, also known as voters. People behave strange, follow destructive rules, cheat, steal, nothing is enough for them, etc. Who does understand this? The elite raises the question, and the programs for correction quickly begin to appear also by politicians and scientists. Changing voters and keeping the votes at the same time however is almost mission impossible. B. F. Skinner made a solution for this challenge that made Burgess angry, and that is why we can write, read, dispute about the masterpiece called A Clockwork Orange for more than a half-century.

As Skinner states ,the so-called 'democratic philosophy' of human behavior to which it also gave rise is increasingly in conflict with the application of the methods of science to human affairs. Unless this conflict is somehow resolved, the ultimate goals of democracy may be long deferred". ${ }^{7}$ Skinner gives a plan - a description about the conflict, and a cure for the symptoms, but not for the basic problem. His cure changes behavior, as if man were a circus animal, says Burgess. Conditioning - he notes - only ensure self discipline, as a built in patrol against autonomy of the self. Without identifying the problem, namely the clockwork condition, alienation, malaise the cure will be ineffective. Skinner identifies only misbehave, that must be cured scientifically and effectively.

Heidegger revealed the problem well in one of his writing about Nietzsche. As he points out in The Word of Nietzsche: ,God is Dead', quoting from The Gay Science by Nietzsche » „We have killed him-you and I. All of us are his murderers,” he allows the madman to as: „But how have we done this?" Nietzsche elucidates the question as he repeats it, spelling out what is asked in three image: „How were we able to drink up the sea? Who gave us the sponge to wipe away the entire horizon? What did we do when we unchained this earth from its sun?" $\ll^{8}$ Without transcendency, without the belief of God mankind lost his sun in the past three decades. What

\footnotetext{
BURGESS 2012.

MARCUSe 2004. 44.

7 SKINNER 1961. 3.

8 HeIDEgGer 1977. 107.
} 
remained is science, which is for almost all is reduced to narrow-minded materialism, even scientists are blind to those disciplines that differ from the one they are dealing with. Capitalism bundled in materialism is the torch with which people regard the earth. Their goals and actions accord no more with transcendency, there have been no value system given by God anymore, humans' task is to correspond earthly wishes with earthly law. No more redemption and the wishes, plans, and self-restraint depends on the individual's intellect, social background, and other profane factors.

Everyone is at the market: producing and consuming are tangled in the same person. At the same time, many kinds of industries strive to plant the abundance of wishes and goals in the subjects' minds, make them want to possess and discard endless sequences of products and buy everything every time at every age. Besides turning off the transcendent light or sun which helped them to see their goals man also „drink up the sea”, all that archaic unity that lay under the sun - all that remained has been raw material: coal, wood, oil, water, stone, meat, etc. And if someone nowadays is ,green” enough, sun, water, wind, or the heat of the soil at first place are renewable energy sources for him or her. Without the sea and the sun, the well-known horizon also vanished, and the familiar world soon became a memory, or rather a fairytale. Today everything is changing on the facade, everyone is rushing, even learning is lifelong, but rules, clocks, and „sirs" are the stable points in ,the vertigo and whirl of our frenzied life”.

In his 1977 Spiegel interview which has a telling title - Only a God Can Save Us - Heidegger exposes his worries for what is so sinister about the 20th century. „Everything is functioning. This is exactly what is so uncanny, that everything is functioning and that the functioning drives us more and more to even further functioning, and that technology tears men loose from the earth and uproots them."

Focusing on the world of Alex we can see a kind of result of vertigo and whirl of millions' frenzied life in an imaginary Britain where anomie is a basic part of life. As Burgess told in many forums the theme of the novel is free will, which is very important to him as a writer with a catholic background. In an interview he tells something very serious: ,...choice, choice is all that matters and to impose the good is evil, to act evil is better than to have good imposed". ${ }^{10}$ Again, we can see that autonomy is competing with heteronomy, the possibility of originality versus artificial or opportunist, also known as civilized actions. Blocking honest actions of humans for requiring the awaited behavior pattern for making a machine-like well doer scientifically is lower class than an honest act even it is bad - that is what Burgess tries to tell. The absolute denial of choice and free will make this kind of technological and medical method a dead-end, for it turns society into an orchestra that plays only its actual conductor's music, with no possibility of improvisation.

Burgess was rightly worried about the fact that this conception would be a real alternative for politicians. Skinner handled conditioning and chemical treatment as a good and reliable solution for the repair of social problems of democratic countries and if he had found supporters, the plan would have been realized.

But even without this direct freedom reducing scientific intervention, choice is still often missing from the lives of people who live in a modern state among non-dystopic circumstances.

9 Only a God Can Save Us: Der Spiegel's Interview. 37.

10 INGerSOLL - INGERSOLL 2008. 8. 
„For the moment, I have to record that I have been derided and rebuked for expressing my fears of the power of the modern state - whether it be Russia, China, or what we may term Anglo-America - to reduce the freedom of the individual"11 says Burgess. It is not accidental that he uses the expression wage-slave depicting people who are not so successful and lucky as he himself is. The majority has been thrown into a situation of surviving and not choosing a job but finds one, and seldom is happy with it. „The maintenance of a complex society depends increasingly on routine work, work with no zest or creativity. The things we eat, clothes we wear, places where we live become increasingly standardized because standardization is the price we pay for the prices we are able to pay. Life ticks along for most of us like a Woolworth's alarm clock. We grow used to the rhythm imposed on us by our need to subsist: soon we get to like our bondage."12

Liking the bondages is often a reaction by people to the facts of modern reality and its dysfunctions. Modernity needs these dysfunctions to be able to function. In democracies, there is liberty and equality, but for example at workplaces - where people spend more than half of their wakefulness - we do not find it often: instead of equality we can see caste systems with rules, clocks, and ,sirs” to the extent that we, who maintain these societies deserve. A typical example for this environment, as Burgess tells it, is the army where drill and commands determine the actions of the soldier and to do so transforms the individual into a tiny particle of the collective. „At first I resented the discipline, the removal of even minimal liberty ... Soon my reduction to a piece of clockwork began to please me, soothe me. One of a squad, obeying orders with the whole squad, forbidden to ask questions or to question orders-I was, after four years of rigorous academic life, having a delicious vacation from the need to be /choosing/ all the time. I can, after six years of that, sympathize with the civilian who is unhappy about making his own decisions - where to eat, whom to vote for, what to wear." ${ }^{13}$ Conformity is indeed a soft pillow for hundreds of millions on which they can sleepwalk their entire life without doing anything original or interesting or valuable that exceeds satisfactory „functioning”. They are, we are human resource, ordered to do something (anything) humanly possible, or as Heidegger calls this, being in the state of the ,standing reserve”.

Such is capitalism, we could say, and all of us saw that the experiments to reform or supersede capitalism became nightmares in the 20th century. As Burgess admits ,, a man has to conform to a pattern of work in order to feed himself and his family; a man may find it pleasurable or natural or convenient to conform in his social tastes". ${ }^{14}$ Then he continues with a warning: „,but when patterns of conformity are imposed by the state, then one has a right to be frightened." ${ }^{15}$ The remote, impersonal governing machine can turn into an inhuman minority group, mainly in big countries or federations. Democracy is not enough strong to hinder the formation of such a government, thus conformity is dangerous if it becomes too widespread. That is why a dose of fear from politicians and the state is really useful as keeping distance from conformity, plus one useful thing: reading dystopias - these are the advice of Burgess for all who want to understand something about the ,clockwork condition”.

\footnotetext{
11 Burgess 2012.

12 Ibid

13 Ibid

14 Ibid

15 Ibid; Rorty 1995.
} 


\section{REFERENCES}

Burgess, Anthony (2012) The Clockwork Condition. The author comments on his most famous book in 1973. http://www.newyorker.com/magazine/2012/06/04/the-clockwork-condition (letöltve: 2021. december 7.)

Heidegger, Martin (1977): The Word of Nietzsche: ,God is Dead'. In Martin Heidegger: The Question Concerning Technology and Other Essays. Translated by William Lovitt. New York \& London, Garland Publishing INC.

Ingersoll Earl G. - Ingersoll Mary C. (2008): Conversations With Anthony Burgess. University Press of Missisipi.

Marcuse, Herbert (2004): Some Social Implications of Modern Technology. In.: Technology, War and Fascism. Taylor \& Francis e-Library.

Nordau Max (1895): Degeneration. New York, D. Appleton and Company.

Only a God Can Save Us: Der Spiegel's Interview. In Manfred Stassen (ed): Martin Heidegger: Philosophical and Political Writings. New York-London, Continuum Publishing Group. 2003.

RORTY RICHARD (1995): Contingency, irony and solidarity. Cambridge University Press.

Skinner, Burrhus Frederic (1961): Freedom and the Control of Men. In Skinner, Burrhus Frederic: Cumulative Record. Appleton-Century-Crofts. 